\title{
THE RIGHT TO A TRIAL WITHIN A REASONABLE TIME: A GENERAL GUARANTEE OF THE RIGHT TO A PENAL EQUITY TRIAL
}

\author{
Georgeta Valeria Sabău
}

\author{
G. V.Sabău
}

Faculty of Law, " Vasile Goldiş" Western University, Arad, Romania

* Correspondesnce: Georgeta Valeria Sabău, "Vasile Goldiş" Western University, 94

Revoluției Bdl., Arad, Romania

E-mail: georgetasabau@yahoo.com

\section{Abstract}

The present article examines the judicial protection of the persons confronted with the non-application of a coherent legislation at a European level, during a penal trial, which can present the risk of generating different standards of protection of the right to a fair trial of the defendant (for the exceeding or hasting excessively the judicial procedure, according to the individual option of every European state.

Keywords: reasonable time, presumption of innocence, right to a fair trial

\section{General considerations regarding the right to a fair trial ${ }^{\mathbf{1}}$}

Respecting the fundamental human rights and freedoms is not only understood as a condition of legality, but also as an expression of the democratic character of the society as a whole.

Implying minimum standards of protection and not being treated exhaustively, most of the rights provided by the European Convention for the protection of fundamental human rights and freedoms ${ }^{2}$ are limited in what concerns the conditions of protection of national security, public safety, economic interest or crime prevention although most of them are of civil or political nature.

Instituted by article $6^{3}$ of the European Convention, the right to a fair trial insures the parties of the trial the guarantee that their rights and freedoms will be respected in court. Practically, this right offers the parties several guarantees to keeping the

\footnotetext{
${ }^{1}$ In Romanian Law, the right to a fair trial is established by article 21 in the Constitution (free access to justice) both in penal and civil matters and by article 10 of Law 304 of 2004 concerning the judicial organization (the last amendment happening by Government Decision no. 666 of the 4th of July 2012, published in the Romanian Official Monitor, Part I, no. 481 of the 13th of July 2012), according to which All persons are entitled to a fair trial and the solution of the accounts within reasonable time... In penal matters, the provisions of article 6, paragraph 2, Penal Procedure Code, meaning regardless of the procedural phase of the cause, both criminal prosecution bodies and courts have the obligation to insure the suspects and the people involved in the account, the specific procedural guarantees, which result from a fair trial.

${ }^{2}$ The Convention for the protection of fundamental human rights and freedoms, also known as the European Convention of Human Rights, signed on the 4th of November 1950 in Rome, enacted on the 3rd of September 1953 and ratified by Romania through Law no.30/1994, regarding the ratification of the Convention for the protection of fundamental human rights and freedoms and the additional protocols of this convention, published in the Romanian Official Monitor, part I, no. 135 of the 31st of March 1994.

${ }^{3}$ According to article 6, paragraph 1 any person has the right to a fair and public trial within a reasonable time, by an independent and impartial court, instituted by law, which will determine either on the infringement of their rights and obligations with a civil character, or on the sturdiness of any accusation in penal matters against them. We find a similar provision in article 47, paragraph 2 of the European Union Charta of Fundamental Rights (2007/C 303/01), in the sense that any person has the right to a fair and public trial within reasonable time in front of an independent and impartial court, having already been constituted by law.

${ }^{4}$ This right is also consecrated by the European Commission Green Card, entitled The Procedural Guarantees given to suspects and people involved in the account in penal procedures in the European Union (COM/2003/0075, finally accessible at http://eur-lex.europa.eu) offering these people the right to the judicial
} 
procedure fair, respectively, the right to a trial within a reasonable time; the guarantee of the presumption of innocence of the defendant; the right to independent and impartial court, instituted by law; the right to publicity of the trial; the principle of "equal weapons " and contradictionality; the right to silence and not self-incrimination of the defendant; the right to defence, and the obligation of the courts to motivate their decisions.

The estimation criteria of the E.C.H.R. in the determination of the infringement of the right to a trial within a reasonable time

Although it is a theme debated by the Romanian and foreign doctrine ${ }^{5}$, exceeding the reasonable time of solving a penal account constitutes one of the most frequent heads of claim brought to the European Court.

Lately, the provisions of article 6, paragraph 1 of the European Convention of Human Rights, which use the collocation "reasonable time", although considered a "minimum limit", separating the abidance and non-abidance by the Convention, are easily replaced by another, respectively "optimum and predictable term" (quantifiable), which will also be the new aim of judicial systems, regardless of the fact that it means the common law courts or specialized courts ${ }^{6}$. We believe that this collocation better identifies the time interval when the entire judicial procedure should develop because a too fast procedure would also affect the right of the petitioner to a fair trial, meaning that the term could be unreasonable due to the haste with which it was developed by the judicial bodies.

The starting point (dies a quo) of the calculation of the reasonable penal term does not coincide with the civil one. In what concerns the guarantee of a reasonable time, timewise, the moment when the prosecution against a person is officially stated will be considered ${ }^{7}$; this moment may coincide with the date of the arrest, of the beginning of the prosecution or the date of announcement of the indictment, respectively the date when the prosecution was officially announced as an official notification provided by a competent authority who accuses a suspect, therefore, even the detention, arrest or execution of a court order.

Those entitled to such a right are natural or legal persons, subjected to pending penal inquiries, and the period of time, which is considered point terminus of the guarantee (dies ad quem) - is either that of the announcement of a final solution concerning the account ${ }^{8}$ (be it definitive conviction court orders, remit court orders, acquittal court orders or non-prosecution curt orders).

The exceptions to the insurance of guarantees provided by article 6 paragraph 1 are the accounts to be revised, in definitive procedures and also rendition procedures ${ }^{9}$.

assistance of a lawyer, chosen of given ex officio, the right to be assisted by a qualified or tolerated interpreter and/or translator, the protection of vulnerable people, the right to knowledge of the existence of their rights and the right to consular assistance.

${ }^{5}$ M. Udroiu, O. Predescu, European Protection of Human Rights and the Romanian Trial. Treated, C.H. Beck Publishing House, Bucharest, 2008, pp. 638-647; R.ChiriȚă, The Right to a Fair Trial, Judicial Universe Publishing House, Bucharest:, 2008, pp. 276-289; C. Bîrsan, The European Convention of Human Rights. Article Commentary. Rights and freedoms, vol. I, Judicial Universe Publishing House, Bucharest, 2005, pp. 533-540; B. Selejan-GuȚan, European Protection of Human Rights, second edition, Judicial Universe Publishing House, Bucharest, 2006, pp. 108-120; M. Udroiu, O. Predescu, Reasonable Time of Penal Procedures, Law Magazine, No.2, 2009, pp. 233-241; J-F. Renucci, Treaty of European human rights law, Hamangiu Publishing House, Bucharest, 2009, pp. 460-470; J. Pradel, La célérité et les temps du proces penal. Comparation entre quelques législation européennes, Compendiu Ottenhof, Dalloz Publishing House, 2003, pp. 251 and these.

${ }^{6}$ For more details, see: the European Union Program for the Efficiency of Justice (EUPEJ), entitled "A new goal for judicial systems: processing each case in an optimum and quantifiable time-frame", reminded by M. Tabarca, The principle of Law in a fair trial, in optimum and predictable time, in the light of the new Code of civil procedure, in Law magazine, no. 12/2010, pp. $42-56$.

See E.C.H.M., decision if the 30th of November 2001, in account Šleževičius versus Lithuania, Paragraph 2331. We metnion that all E.C.H.M. decisions in this material are accessible on the website www.echr.coe.int.

${ }^{8}$ It holds no relevance whether the person has been definitively convicted in contumacy (E.C.H.M., decision on the $9^{\text {th }}$ of September 2003, in the account Jones versus the United Kingdom; E.C.H.M., decision on the $10^{\text {th }}$ of November 2004, in the account Sejdovic versus Italy).

${ }^{9}$ See E.C.H.M, decision on the $6^{\text {th }}$ of February 2003, in the account Mamatkulov and Abdurasulovic versus Turkey, paragraph 80 . 
Although neither has a decisive character, the European Court of Human Rights set four estimation criteria, thoroughly analysing each account, taking into consideration the criterion of behaviour of the parties, the authorities, the importance of the object of the procedure for the party involved and the criterion of the complexity of the cause as a whole.

In certain situations, the parties' behaviour, often the claimer's behaviour, may be the cause of procedural delay, in which case it can be imputed an insufficient diligence in cooperating with judicial authorities, such as the excessive change of defenders, the delay in submitting the written conclusions that are indispensable for the judicial procedure. Moreover, in the judicial practice ${ }^{10}$ it was questioned whether the abusive use of the means of attack could constitute a dilatory behaviour of the claimer in the conclusion of his/her judicial procedure.

\section{Fair trial versus reasonable time}

In what concerns the lack of a reasonable time necessary to the claimer in order to contest the declarations on which his/her conviction was based, the account Lucâ versus Italy is representative ${ }^{11}$. In fact, N. and C., being found to have a certain quantity of cocaine, were arrested. On this occasion, N. declared that $\mathrm{C}$. and he went to the claimer, who was willing to supply them with a certain quantity of cocaine. At first, $\mathrm{N}$. was considered a mere witness, but then he was interrogated by the attorney as the accused. The claimer and $\mathrm{C}$. were arraigned for drug traffic and N. was charged in a different trial for drug possession. Summoned as a witness in the claimer's trial and as a defendant in a related trial N. used his right to remain silent. Thus, the claimer could not ask any questions or determine him to make a statement. In this situation, the Court acknowledged N.'s refusal to testify and used the possibility provided by the law, according to the Constitutional Court, of using the statements made by defendants in related procedures. Therefore, the records of evidence of N.'s statements to the attorney were read in court.

The claimer was sentenced to 8 years of prison and a fine and the appeal and recourse were denied.

All ways of attack having been used, the claimer addressed the European Court of Human Rights claiming that the solution of Italian courts was announced violating the principle of contradictionality.

Examining the reasons appealed to and the documents presented, the Court estimated that any pieces of evidence must, as a rule, be administered in the presence of the defendant in a public meeting in order to be submitted to a contradictory debate. This principle, even if it may have some exceptions, cannot prejudice the right to defence of the claimer. If a conviction is exclusively or largely based on the depositions of a person whom the defendant has not had the possibility to interrogate or to have that person interrogated, the right to defence is limited in an incompatible way with the requirements of article 6 in the European Convention.

In this case, the courts exclusively based on the depositions made by N. prior to the trial, when neither the claimer, nor his attorney had the possibility of interrogating him. Hence, the claimer did not have an adequate and sufficient occasion to contest the declarations on which his conviction was based. As a consequence, the Court unanimously acknowledged an infringement of article 6, paragraph 1 in the European Convention.

In another account, - Schumacher versus Luxembourg ${ }^{12}$ - the claimer was charged for money laundering through drug traffic. Several investigations were made, especially with the help of international rogatory commissions. On the $17^{\text {th }}$ of November 2000 , it was settled that the penal procedure had already been prescribed because there was no criminal prosecution made in the last three years.

The European Court considered that, in such a situation, the final step of the procedure is that of the edict of release from criminal prosecution so as up to that date, the

\footnotetext{
${ }^{10}$ See E.C.H.M, decision on the $27^{\text {th }}$ of April 2008, in the account Heremans versus Belgium, paragraph 17-43.

${ }^{11}$ See E.C.H.M, decision on the 27th of May 2001, in the account Lucâ versus Italy, paragraph 31-45.

${ }^{12}$ See E.C.H.M, decision on the 25th of November 2003, in the account Schumacher versus Luxembourg, paragraph 23-36.
} 
defendant is waiting for the solution of his/her file. In regard to the reasonable character of this duration, the Court ascertained that in three years' time there has been no act of procedure, so there was an immense period of inactivity of the criminal prosecution bodies; hence article 6, paragraph 1 was infringed.

The account Ardelean versus Romania ${ }^{13}$, although a recent account, is representative for the infringement of the right to a fair trial. The claimer, an attorney convicted for fraud, among others, complained about the duration of the criminal procedure of his file, claiming that his right to a fair trial within a reasonable time had been infringed.

The Court reiterated the fact that the reasonability of the procedure must be assessed and interpreted according to the circumstances of each pending cause, respectively the complexity of the cause, the claimer's behaviour, the competent authorities in question, emphasising that, in criminal matters, the right to a trial within a reasonable time is important so as not to drag on this state of uncertainty of the defendant.

Although the length of the trial phase of 2 years and 8 months seems to be unreasonable for the two levels of jurisdiction, the Court still estimated that the duration of the procedure was excessive, despite the fact that the account had not been complex; the first sentence was pronounced five years after the beginning of the criminal prosecution, the account being suspended countless times and the exceptions of unconstitutionality presented by the parties suggest a long period of passivity or inactivity in the account, hence, article 6, paragraph 1 was infringed.

Furthermore, in the account Mattocia versus Italy ${ }^{14}$, the E.C.H.R. ascertained that the judicial procedure exceeded the rational duration, but not because of reasons imputable to the petitioner, but to the national authorities, also mentioning that not only the nature of the crime itself catalogues the judicial procedure as being a complex one (in fact, it is about the commission of rape), but the complexity of the account in its whole, under the aspect of the object and size of the file, the number of those inquired and of witnesses to hear, the number and nature of the crimes (often with a cross-border character), examinations, and the duration of procedural acts made by the rogatory commission and rendition procedures.

In the account Mitap and Müftüoglu versus Turkey ${ }^{15}$, the two claimers, arrested in 1981 and sent to court only the next year for political crimes, were convicted to prison for life. After using all the attack methods provided by national legislation, the claimers addressed the European Court of Human Rights, appealing to the excessive duration of the trial, respectively over 14 years (out of which the elaboration of the conviction sentence took no less than 4 years). The commission acquired the reasons invoked by the claimers and noticed E.C.H.R., which established that, although the account was complex, there was no reason to justify such a long duration of the trial.

On the contrary, in another account, Idalov versus Russia ${ }^{16}$, the claimer, arrested in 1999 for several offences of organised crime, invoked in court, among others, that the duration of the trial was excessive, the hearings being postponed by the court repeatedly and baselessly. Meanwhile, the culprit state claimed that the adjournment of the hearings was reasoned, given that they confronted the health deterioration of one of the defendants, the account being a complex one.

Although the European Court acknowledges the complexity if the account, it reiterates the fact that the duration of the procedure must be estimated according to other criteria, respectively the conduct of the claimer and the authorities in question, and the claimer's stake in the pending litigation. The Court noticed that the claimer had been arrested in June, 1999, and the definitive sentence was given in May, 2004. As a result, the duration of the procedure was of 4 years and 11 months but the duration of the procedure in this account

\footnotetext{
${ }^{13}$ See E.C.H.M, decision on the 30th of October 2012, in the account Ardelean versus Romania, paragraph $77-$ 85 .

${ }^{14}$ See E.C.H.M, decision on the 25th of July 2000, in the account Mattoccia versus Italy, paragraph 73-81.

${ }^{15}$ See E.C.H.M, decision on the 25th of March 1996, in the account Muftuoglu and Mitrap versus Turkey, paragraph 29-37.

${ }^{16}$ See E.C.H.M, decision on the 22th of May 2012, in the account Idalov versus Russia, paragraph 165-192.
} 
was largely due to the claimer's postponements. Out of approximately 40 hearings in Court, 11 of them were due to the claimer, which shows that he was not fully diligent for the expedience of the procedure. As a consequence, the Court established that article 6, paragraph1 was not infringed.

Furthermore, in the account Boddaert versus Belgium ${ }^{17}$, the European Court, examining the account and considering that in regard to the objective difficulties of the process, the defendants' attitude of disturbance of the judicial bodies' inquiry, the discovery of new facts, the gravity of the crimes committed, has unanimously decided that there has been no infringement of the right to a fair trial.

This was also the solution in the account Nevskaya versus Russia ${ }^{18}$, where, after having made an ensemble assessment of the circumstances of the account, the Court estimates that the reasonable time has been respected, despite the fact that the claimer cannot be compelled to actively cooperate with the judicial authorities and not all methods of attack have been used having the domestic legislation defending his/her interests.

\section{Substitutes for conclusions}

1. Both jurisprudence and the doctrine in the matter estimate that the determination of the reasonable duration, although being considered a demand of expedience of the trial, may sometimes create certain difficulties of interpretation.

2. Skimming over the small jurisprudence catalogue concerning the field of application of article 6 , paragraph 1 of the Convention, we can easily notice that the excessive duration constitute a major problem in most member states, characterised by either passive or inactive behaviours of the authorities, by repeated adjournments of hearings, of competence refusals, procedure vices, etc.

3. Therefore, the infringement of the guarantee of the right to a fair trial by exceeding the reasonable time of penal procedures is due to commissive or omissive behaviours of the states and those that have not been effectively improved in national courts may be submitted to the European Court of Human Rights, a court that can grant a fair reparation.

\section{Bibliography}

M. Tăbârcă, The principle of Law in a fair trial, in optimum and predictable time, in the light of the new Code of civil procedure, in Law magazine, no. 12/2010;

J-F. Renucci, Treaty of European human rights law, Hamangiu Publishing House, Bucharest 2009; 2009;

M. Udroiu, O. Predescu, Reasonable Time of Penal Procedures, Law Magazine, No. 2,

R.ChiriȚă, The Right to a Fair Trial, Judicial Universe Publishing House, Bucharest, 2008;

M. Udroiu, O. Predescu, European Protection of Human Rights and the Romanian Trial. Treated, C.H. Beck Publishing House, Bucharest, 2008;

B. Selejan-GuT,an, European Protection of Human Rights, second edition, Judicial Universe Publishing House, Bucharest, 2006;

C. Bîrsan, The European Convention of Human Rights. Article Commentary. Rights and freedoms, vol. I, Judicial Universe Publishing House, Bucharest, 2005;

J. Pradel, La célérité et les temps du proces pénal. Comparation entre quelques législation européennes, Compendiu Ottenhof, Dalloz Publishing House, 2003.

\footnotetext{
${ }^{17}$ See E.C.H.M, decision on the 12th of October 1992, in the account Boddaert versus Belgium, paragraph $165-$ 192.

${ }^{18}$ See E.C.H.M, decision on the 11th of October 2011, in the account Nevskaya versus Russia, paragraph 18-28.
} 